\title{
Transformation of the Cyanobacterium Synechococcus PCC 6301 Using Cloned DNA
}

\author{
By D. A. LightFoot, $\dagger$ D. E. WALTERS AND J. C. WOOTTON* \\ Department of Genetics, University of Leeds, Leeds LS2 9JT, UK
}

(Received 12 February 1988)

\begin{abstract}
Stable ampicillin-resistant transformants of Synechococcus PCC 6301 were isolated using as donor fragments chromosomal DNA cloned into ColE1-derived vectors. Using dark-incubated recipient cells, transformation was achieved reproducibly at frequencies of approximately $10^{-5}$ per cell and $3 \times 10^{2}$ per $\mu \mathrm{g}$ of donor DNA. These frequencies were $10^{2}$ - to $10^{4}$-fold lower than those reported previously by other workers for the closely related strain PCC 7942 but only 5- to 10 -fold lower than found by us in parallel experiments with both strains. Different donor fragments of PCC 6301 DNA gave different characteristic transformation frequencies which were greatly reduced by short internal deletions. The results are most simply explained by a model of integration of circular plasmid DNA into the recipient chromosome by a single crossover event.
\end{abstract}

\section{INTRODUCTION}

Transformation of some strains of the unicellular cyanobacterium Synechococcus, associated with incubation of cells in the presence of homologous DNA, is documented (Shestakov \& Khyen, 1970; Orkwiszewski \& Kaney, 1974; Grigorieva \& Shestakov, 1976; Grigorieva, 1985). In some cyanobacteria it is possible to follow the fate of the presumed transforming DNA with genetic markers (Astier \& Joset-Espardelier, 1976; Stevens \& Porter, 1980; Williams \& Szalay, 1983) or radiolabelling (Shestakov et al., 1982). Recombination between plasmid-borne chromosomal fragments and the homologous region in the chromosome of the recipient cell occurs at high frequency in strains such as Synechococcus PCC 7942 and Synechococcus PCC 7002 (Williams \& Szalay, 1983; Buzby et al., 1983).

The work described in this paper was done with Synechococcus PCC 6301, a strain for which a great deal of biochemical and genetic information has been amassed (Herdman, 1982). Transformants of this strain have been isolated following incubation of cells with chromosomal DNA (Herdman 1973; Orkwiszewski \& Kaney, 1974), but integrative transformation of PCC 6301, detected by selection for donor antibiotic-resistance markers, has not been reported. It has been suggested that during laboratory culture this strain has lost the ability to take up, assimilate or maintain exogenous DNA (Kuhlemeier, 1984). We now report the stable and reproducible transformation of Synechococcus PCC 6301 using donor chimaeric plasmids carrying inserts of Synechococcus chromosomal DNA. A simple protocol for transformation is described, involving incubation of recipient cells with donor DNA in darkness followed by selection for the donor ampicillin-resistance marker.

\section{METHODS}

Strains and plasmids. Strains of Synechococcus and Escherichia coli are listed in Table 1. Plasmids are described in Table 1 and Fig. 1.

Media and growth. E. coli CLR207 recA was grown at $37^{\circ} \mathrm{C}$ on L-broth and L-agar plates containing $0 \cdot 2 \%(\mathrm{w} / \mathrm{v})$ glucose. Ampicillin $\left(20 \mu \mathrm{g} \mathrm{ml}^{-1}\right)$ and tetracycline $\left(15 \mu \mathrm{g} \mathrm{ml} \mathrm{m}^{-1}\right)$ were added when required. The strain was periodically selected on tetracycline and tested for UV-sensitivity to confirm Tn 10 inactivation of recA.

† Present address: Department of Horticulture, Oregon State University, Corvallis, OR 97331, USA. 
(a) Random
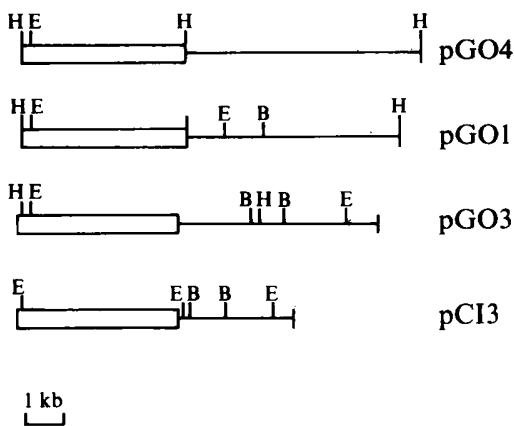

(b) $\mathrm{pDN} 1$ derivatives

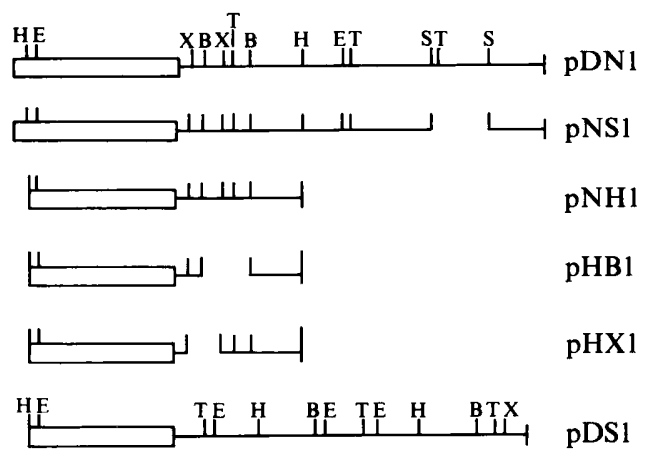

Fig. 1. Linear restriction maps of plasmids used for transformations. Panel (a) shows the recombinant plasmids containing random genomic inserts. Panel $(b)$ shows pDN1 and its derivatives. Sites shown are BamHI (B), BstEII (T), EcoRI (E), HindIII (H), SmaI (S) and XhoI (X).

\section{Table 1. Relevant characteristics of strains and plasmids used}

Strain

E. coli CLR207 recA

Synechococcus PCC 6301

Synechococcus PCC 7942

\begin{tabular}{|c|c|}
\hline Plasmid* & $\begin{array}{c}\text { Nature of } \\
\text { insert DNA }\end{array}$ \\
\hline pGO1 & $\begin{array}{c}\text { Native } \\
\text { chromosomal }\end{array}$ \\
\hline pGO4 & $\begin{array}{c}\text { Native } \\
\text { chromosomal }\end{array}$ \\
\hline pGO3 & $\begin{array}{c}\text { Native } \\
\text { chromosomal }\end{array}$ \\
\hline pDN1 & $\begin{array}{c}\text { Native } \\
\text { chromosomal }\end{array}$ \\
\hline pDS1 & $\begin{array}{l}\text { Duplication of } \\
\text { pDN1 sequences }\end{array}$ \\
\hline pNH1 & Deletion of pDN1 \\
\hline $\mathrm{pCI} 3$ & $\begin{array}{c}\text { Native } \\
\text { chromosomal }\end{array}$ \\
\hline pHB1 & $\begin{array}{l}\text { Internal deletion } \\
\text { of } 1.3 \mathrm{kbp}\end{array}$ \\
\hline pHX1 & $\begin{array}{l}\text { Internal deletion } \\
\text { of } 1.0 \mathrm{kbp}\end{array}$ \\
\hline pNS1 & $\begin{array}{l}\text { Internal deletion } \\
\text { of } 1.5 \mathrm{kbp}\end{array}$ \\
\hline $\begin{array}{l}\text { pBR322 } \\
\text { pRK9 }\end{array}$ & $\begin{array}{l}\text { None } \\
\text { None }\end{array}$ \\
\hline
\end{tabular}

Source or reference

Mattaj et al. (1982)

N. G. Carr

C. Kuhlemeier

$\begin{gathered}\text { Size of } \\ \text { plasmid (kbp) }\end{gathered}$
$9 \cdot 5$
$10 \cdot 1$
$8 \cdot 9$
$13 \cdot 5$
$13 \cdot 0$
$7 \cdot 0$
7.0
5.7
6.0
$12 \cdot 0$
4.3
$4 \cdot 1$

\section{Relevant characters}

Tc, $\operatorname{rec} A$

Wild-type

Wild-type

Relevant

Vector

pBR322

(H)

pBR322

(H)

pRK9

(B)

pBR322

(B)

pRK9

(B)

pBR322

(B, H)

pRK9

(B)

pBR322

(B, H, B)

pBR322

(B, H, X)

pBR322

(B, N, S)

characters

Ap

Ap

Ap

Ap

Ap

Ap

Ap

Ap

Ap

Ap

Ap, Tc

Ap

* All plasmids except pBR322 and pRK9 were constructed in this work (see text for details).

† Letters in parenthesis indicate the restriction site in the vector used for cloning; the second of two indicates a vector site used to construct deletions of the chimaeric plasmids and the third of three indicates the pair of sites in the insert used to construct internal deletions (B, BamHI; H, HindIII; N, none; S, SmaI; X, XhoI).

Medium BG-11 (Rippka et al., 1979) was used for growth of all cyanobacterial strains. The components of the medium were made up separately, at 200 times the working concentration, in double-distilled water and sterilized by autoclaving. Medium containing agar was made by sterilizing $0.85 \%(w / v)$ Difco agar in double-distilled water and adding medium components after cooling to $55^{\circ} \mathrm{C}$. Ampicillin was added at $2 \mu \mathrm{g} \mathrm{ml}^{-1}$. The source of ampicillin was very important: Amphipen (sodium ampicillin BP, for intramuscular use), as supplied by Brocades 
Ltd, was satisfactory indefinitely if stored dry at $-20^{\circ} \mathrm{C}$ or for one month in solution at $-20^{\circ} \mathrm{C}$. Liquid cultures were incubated at $30^{\circ} \mathrm{C}$, with $10 \mathrm{~W} \mathrm{~m}^{-2}$ fluorescent white light, and vigorous aeration. Agar plates were incubated at $30^{\circ} \mathrm{C}$, with $3 \mathrm{~W} \mathrm{~m}^{-2}$ white light in a Gallenkamp illuminated incubator.

Cloning strategies. A gene library was constructed from Synechococcus PCC 6301 chromosomal DNA and two plasmid vectors, pBR322 and the derived expression vector pRK9 (Schechtman \& Yanofsky, 1983). The chromosomal DNA was either partially digested to an average length of $3 \mathrm{kbp}$ with Sau3A and ligated into the $B a m H I$ site of both plasmid vectors or digested to completion with HindIII and ligated into the HindIII site of pBR322. Recombinant plasmids were transformed into the multiply-auxotrophic $E$. coli strain CLR207 recA (Mattaj et al., 1982). E. coli transformation was done as described by Hanahan (1983). Plasmid DNA was isolated by the method of Ish-Horowicz \& Burke (1981). Restriction maps (Fig. 1) were constructed from single and double digests separated by electrophoresis on $0.8 \%$ agarose gels.

Construction of deleted derivatives from hybrid plasmids. The deleted derivative $\mathrm{pNH} 1$ (Fig. 1) was produced from pDN1 by digestion of plasmid DNA with HindIII followed by religation and transformation into $E$. coli. The internal deletions (Fig. 1) were constructed by restriction endonuclease digestion of the plasmids pDN1 and pNH1 with enzymes known to cleave twice within the DNA of cyanobacterial origin but not the vector, followed by religation at low DNA concentration. BamHI, XhoI and $S m a I$ were used to produce the derivatives $\mathrm{pHB} 1, \mathrm{pHX} 1$ and pNS1 respectively. Plasmid pDS1 was constructed by ligation of a partial Sau3A digest of pDN1 DNA into the BamHI site of pRK9. Restriction analysis showed that multiple fragment insertions occurred, producing a tandem repeat structure (Fig. 1).

Synechococcus transformation protocol. Typically a liquid culture $(50 \mathrm{ml})$ was grown to an $\mathrm{OD}_{660}$ of 1.0 (approximately $2 \times 10^{8}$ c.f.u. $\mathrm{ml}^{-1}$ ). Cells were centrifuged $(8000 \mathrm{~g}, 10 \mathrm{~min}$ ) and resuspended in half the volume of fresh BG-11 medium. Samples (1 ml) were transferred to polycarbonate tubes (Sterilin) containing $0 \cdot 3,1.0$ or $10 \mu \mathrm{g}$ of the transforming DNA. The tubes were wrapped in aluminium foil to exclude light and incubated at $30^{\circ} \mathrm{C}$ overnight before being incubated for a further $6 \mathrm{~h}$ in the light $\left(3 \mathrm{~W} \mathrm{~m}^{-2}\right)$. Samples of up to $0 \cdot 1 \mathrm{ml}$ were plated directly onto fresh, undried, BG-11 plates containing ampicillin. The plates were incubated for $4 \mathrm{~h}$ before inverting to allow the surface of the plate to dry. Incubation was continued for 20-30 d to allow large colonies to form. The $\mathrm{Ap}^{\mathrm{r}}$ phenotype of putative transformed colonies was verified by restreaking on fresh BG-11 plates containing ampicillin. After incubation these plates were used to inoculate liquid cultures (50 ml) containing ampicillin. Total DNA was extracted from these cells by the method of Mazur et al. (1980) for analysis by Southern hybridization (Southern, 1975).

\section{RESULTS AND DISCUSSION}

\section{Transformation of recipient cells incubated in the light}

Duplication of the original transformation protocol for Synechococcus PCC 6301 (Herdman, 1973) failed to produce any $\mathrm{Ap}^{\mathrm{r}}$ colonies with either pBR322 or pDN1 DNA, despite elevated DNA concentrations (to $20 \mu \mathrm{g} \mathrm{ml}^{-1}$ ). A $24 \mathrm{~h}$ growth period on non-selective medium facilitated the recovery of a few transformants, probably by permitting the expression of the incoming foreign gene. Seven stable Apr colonies were isolated from cells treated with pDN1 DNA, but none could be detected from the parallel pBR322 transformations. Controls of untreated cells or DNA alone failed to produce $\mathrm{Ap}^{\mathrm{r}}$ colonies; since titrations of treated cells on media lacking antibiotic showed that $3 \times 10^{8}$ c.f.u. were plated $\left(10^{8}\right.$ c.f.u., three plates), the spontaneous mutation rate to this level of $\mathrm{Ap}^{\mathrm{r}}$ was less than $3 \times 10^{-8}$ per cell. The transformation frequency detected was $4.2 \times 10^{-7}$ per cell or one transformant per $\mu$ g DNA. Transformation of PCC 6301 by this method thus gave unsatisfactorily low frequencies.

\section{Transformation of recipient cells incubated in the dark}

A increase of at least 100-fold in the transformation frequency of strain PCC 6301 was observed when the cells were incubated with DNA in darkness, similar to that reported by Golden \& Sherman (1984) with strain PCC 7942. Table 2 shows the frequencies with which stable Ap ${ }^{T}$ colonies were obtained from samples of cultures of PCC 6301 treated in parallel with one of a number of plasmids. Between two and eight independent transformation experiments were made with each plasmid. Transformants were obtained only from donor plasmids carrying inserts of Synechococcus DNA. No stable Ap ${ }^{\mathrm{r}}$ colonies were detected from cells treated with pBR322, corresponding to a transformation frequency of less than $10^{-9}$ per cell, or less than 0.02 transformants per $\mu \mathrm{g}$ DNA of this vector. 
Table 2. Comparison of transformation frequencies of chimaeric plasmids

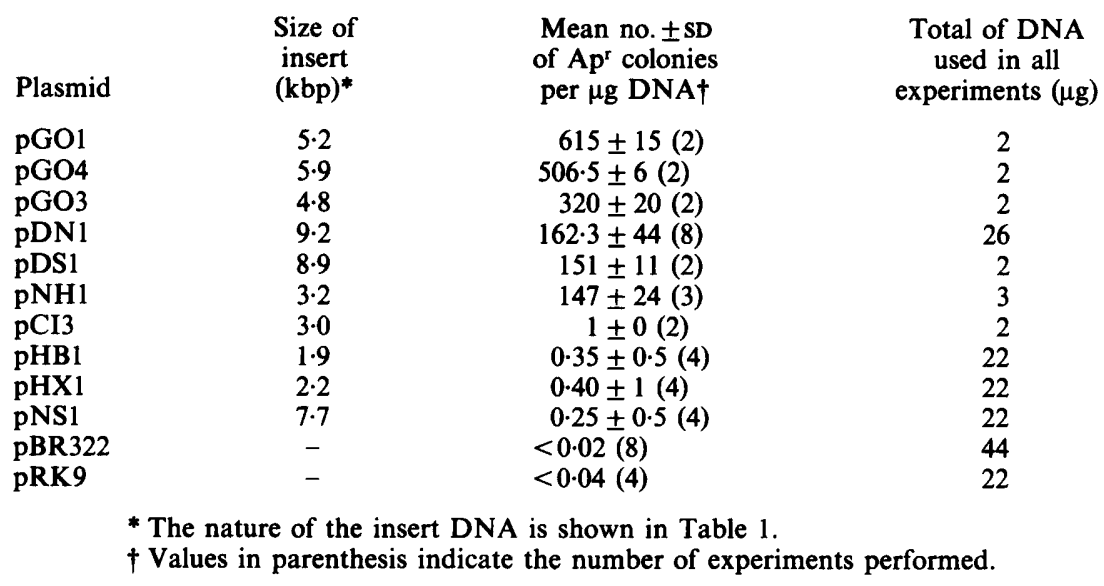

Table 3. Comparison of transformation frequencies of strains PCC 6301 and PCC 7942

The results are from a single representative experiment.

\begin{tabular}{lccc} 
& \multicolumn{2}{c}{$\begin{array}{c}\text { No. of Ap colonies } \\
\text { per } \mu \text { g DNA }\end{array}$} \\
Plasmid & $\begin{array}{c}\text { DNA } \\
(\mu \mathrm{g})\end{array}$ & $\overbrace{\text { Strain } 6301}$ & Strain 7942 \\
pDN1 & 1 & 137 & 1200 \\
pHB1 & 10 & 1 & 3 \\
pHX1 & 10 & 1 & 5 \\
pNS1 & 10 & 1 & 7 \\
pBR322 & 1 & 0 & 0
\end{tabular}

\section{Effect of size and continuity of donor DNA on transformation}

Donor plasmids carrying different inserts of native Synechococcus chromosomal DNA gave characteristic transformation frequencies varying from 1 to 615 transformants per $\mu \mathrm{g}$ of donor DNA (Table 2). The size of the homologous DNA seemed to exert an effect within the range tested (3-10 kbp), with optimal recovery of transformants being obtained from plasmids with inserts in the 5-6 kbp range. Internal deletions of the insert, which interrupted the linear sequence of the cyanobacterial DNA, decreased the transformation efficiencies more than 100fold, indicating that transformation required structural integrity of the homologous DNA. Transformation with these deleted derivatives required elevated DNA concentrations, 10-fold higher $\left(10 \mu \mathrm{g} \mathrm{ml}^{-1}\right)$ than that found to be saturating in transformations with pDN1.

\section{Parallel transformation of PCC 6301 and PCC 7942}

The same plasmids were used to transform two separate Synechococcus strains in parallel experiments (Table 3). Strain PCC 7942 shows high transformation frequencies with homologous DNA sequences (Williams \& Szalay, 1983; Golden \& Sherman 1984). Internal deletions within the homologous DNA resulted in decreases in transformation frequencies for both PCC 7942 and PCC 6301, although the frequencies were 3- to 10-fold higher overall with PCC 7942 as recipient (Table 3).

\section{State of transforming DNA}

A number of stable Ap ${ }^{\mathrm{r}}$ colonies derived from pDN1 transformations with both light- and dark-treated cells of strain PCC 6301 were shown to contain plasmid DNA by Southern hybridization with probes prepared from plasmid sequences. Fig. 2 shows a typical 


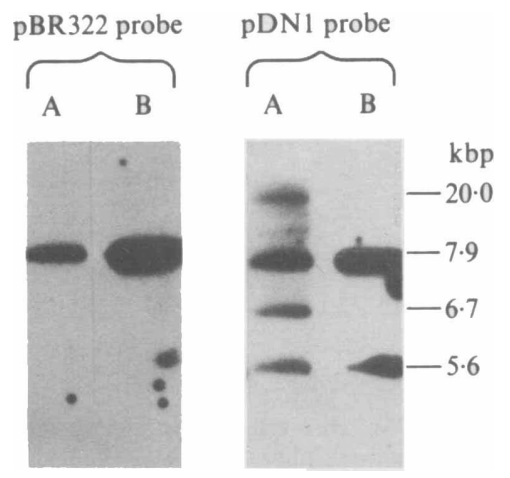

\begin{abstract}
Fig. 2. Hybridization of total genomic DNA to plasmid probes. Total genomic DNA, from a strain of Synechococcus PCC 6301 transformed to ampicillin resistance by incubation with pDN1 (transformant 2.2), and supercoiled pDN1 DNA, purified from $E$. coli, were digested with EcoRI and separated by electrophoresis in $0.8 \%(\mathrm{w} / \mathrm{v})$ agarose at loadings of $3 \mu \mathrm{g}$ and $3 \mathrm{ng}$ respectively. Ethidium bromide staining showed that all samples were digested to completion. After Southern blotting, they were hybridized successively with probes constructed from pBR322 DNA, then pDN1 DNA, each hybridization being followed by washes at high stringency and autoradiography. Lane A contains DNA from transformant 2.2. Lane B contains pDN1 DNA. Sizes of fragments were measured by comparison with $H$ indIII fragments of bacteriophage $\lambda$ DNA.
\end{abstract}

hybridization pattern obtained with restriction digests of DNA from one of these stable $\mathrm{Ap}^{\mathrm{r}}$ strains (transformant 2.2). A single fragment of similar size (7.9 kbp) to that containing the majority of the pBR322 DNA in the transforming plasmid (Fig. 1) hybridized strongly with a probe constructed from pBR322 (Fig. 2); the second fragment produced by EcoRI digestion of pDN1 DNA (5.6 kbp) hybridized weakly, as it only contains $380 \mathrm{bp}$ of sequence from pBR322. Use of $\mathrm{pDN} 1$ as a probe detected these two fragments and two additional fragments ( 20 and $6.7 \mathrm{kbp}$ ) at similar intensities which were the same size as fragments of recipient chromosome detected by probing untransformed Synechococcus PCC 6301 DNA with pDN1 (data not shown). No hybridization was detected in probings of DNA from untransformed Synechococcus PCC 6301 with pBR322 (data not shown). This result does not formally distinguish between the hypotheses of $(a)$ integration of donor DNA by a single homologous crossover, and $(b)$ maintenance of a single-copy autonomously replicating plasmid form of the donor DNA.

The following observations strongly support the integrative model. Probing uncut total DNA of transformant 2.2 with pBR322 established that hybridizing sequences derived from this plasmid were present in the high-molecular-mass DNA $(50-100 \mathrm{kbp}$, data not shown). Additionally, transformation of $E$. coli with the supercoiled fraction of DNA isolated from transformant 2.2 by $\mathrm{CsCl}$ density-gradient centrifugation gave no $\mathrm{Ap}^{r}$ colonies. The equivalent amount of control pDN1 DNA gave $10^{7} \mathrm{Ap}^{\mathrm{r}}$ colonies. $\mathrm{pDN} 1$ is not known to contain a cyanobacterial origin. Further, autonomous maintenance does not provide a plausible explanation for the drastic reduction in transformation frequency caused by internal deletions of the PCC 6301 DNA in the donor plasmids, which very probably reflects an integration mechanism involving homologous recombination.

\title{
Conditions affecting transformation
}

The use of dark conditions for incubation of recipient cells with DNA dramatically increased transformation frequencies of strain PCC 6301 with hybrid plasmids. The reason for this is unknown. Golden \& Sherman (1984) hypothesized that a membrane-bound component involved in photosynthetic ion exchange, and required for DNA uptake, is sequestered during illumination. Shestakov et al. (1982) invoked a similar mechanism to explain the lightdependence of transformation. It seems equally likely that the depressed metabolism of darkened cells might favour uptake, maintenance or stable integration of DNA, or expression of the foreign resistance gene. Differences in our method which might also influence successful 
transformation of strain PCC 6301 include the absence of $\mathrm{CO}_{2}$ enrichment during selection for $\mathrm{Ap}^{\mathrm{r}}$ colonies, and the use of a different medium. Other factors which might affect transformation include the period of incubation of cells with DNA (Daniell \& McFadden, 1986), the genotype of clonal isolates (Williams \& Szalay, 1983) and the source of water (Hanahan, 1985).

Financial support was from an SERC research studentship to D.A.L. and D.E.W. and part of the SERC research grant $\mathrm{GR} / \mathrm{C} / 45836$ to J.C.W.

\section{REFERENCES}

Astier, C. \& Joset-Espardelier, F. (1976). Mise en evidence d'un système de transfert génétique chez une cyanophycée du genre Aphanocapsa. Comptes rendus hebdomadaires des séances de l'Académie des Sciences, Paris D282, 795-797.

Buzby, J. S., Porter, R. D. \& Stevens, S. E. (1983). Plasmid transformation in Agmenellum quadruplicatum PR-6: construction of biphasic plasmids and characterization of their transformation properties. Journal of Bacteriology 154, 1446-1450.

DANiell, H. \& McFadden, B. A. (1986). Characterization of DNA uptake by the cyanobacterium Anacystis nidulans. Molecular and General Genetics 204, 243-248.

Golden, S. S. \& Sherman, L. A. (1984). Optimal conditions for genetic transformation of the cyanobacterium Anacystis nidulans R2. Journal of Bacteriology 158, 36-42.

Grigorieva, G. A. (1985). Heterospecific transformation in cyanobacteria of the genus Synechococcus. Biologicheskie Nauki no. 9, 91-94 (in Russian).

Grigorieva, G. A. \& Shestakov, S. V. (1976). The application of the genetic transformation method for taxonomic analysis of unicellular blue green algae. In Proceedings of the Second International Symposium on Photosynthetic Prokaryotes, pp. 277-280. Edited by G. A. Codd \& W. D. P. Stewart. Dundee, Scotland: University of Dundee.

HANAHAN, D. (1983). Studies on transformation of Escherichia coli with plasmids. Journal of Molecular Biology 166, 557-580.

Hanahan, D. (1985). Techniques for transformation of E. coli. In DNA Cloning, A Practical Approach, vol. I, pp. 109-135. Edited by D. M. Glover. Oxford: IRL Press.

Herdman, M. (1973). Mutations arising during transformation in the blue green alga Anacystis nidulans. Molecular and General Genetics 120, 369-378.

HeRdMAN, M. (1982). Evolution and genetic properties of cyanobacterial genomes. In The Biology of Cyanobacteria, pp. 263-306. Edited by N. G. Carr \& B. A. Whitton. Oxford: Blackwell Scientific Publications.

IsH-HoRowicz, D. \& BURKe, J. F. (1981). Rapid and efficient cosmid vector cloning. Nucleic Acids Research 9, 2989-2998.
KUHLEMEIER, C. J. (1984). Gene cloning in the cyanobacterium Anacystis nidulans $\mathrm{R} 2$. $\mathrm{PhD}$ thesis, University of Utrecht.

mattaj, I. W., McPherson, M. J. \& Wootton, J. C. (1982). Localization of a strongly conserved section of coding sequence in glutamate dehydrogenase genes. FEBS Letters 147, 21-25.

MAZUR, B. J., Rice, D. \& HAzelkoRn, R. (1980). Identification of blue-green algal nitrogen fixation genes by using heterologous DNA hybridization probes. Proceedings of the National Academy of Sciences of the United States of America 77, 186-190.

ORKWISZEWSKI, K. G. \& KANEY, A. R. (1974). Genetic transformation of the blue-green bacterium Anacystis nidulans. Archives of Microbiology 98, 31-37.

RIPPKA, R., DerUelles, J., WATERbURY, J. B., Herdman, M. \& Stanier, R. Y. (1979). Generic assignments, strain histories and properties of pure cultures of cyanobacteria. Journal of General Microbiology 111, 1-61.

SchechtMan, M. G. \& YANOFSKY, C. (1983). Structure of the trifunctional trp-1 gene from Neurospora crassa and its aberrant expression in Escherichia coli. Journal of Molecular and Applied Genetics 2, 83-99.

ShestaRov, S. V. \& KHYEN, N. T. (1970). Evidence for genetic transformation in the blue green alga Anacystis nidulans. Molecular and General Genetics 107, 372-375.

Shestakov, S. V., Karbysheva, E. A. \& Elanskaya, I. V. (1982). The nature of damage in mutants of Anacystis nidulans deficient in genetic transformation. Genetika 18, 1271-1275.

SOUTHERN, E. M. (1975). Detection of specific sequences among DNA fragments separated by gel electrophoresis. Journal of Molecular Biology 98, 503-517.

Stevens, S. E. \& PORTER, R. D. (1980). Transformation in Agmenellum quadruplicatum. Proceedings of the National Academy of Sciences of the United States of America 77, 6052-6056.

Williams, J. G. K. \& Szalay, A. (1983). Stable integration of foreign DNA into the chromosome of the cyanobacterium Synechococcus R2. Gene 24, 3751. 